\title{
EFL Teachers' Attitudes towards Language Learners: A Case of Multicultural Classrooms
}

\section{Martin Kustati}

Dr., corresponding author, Imam Bonjol State Islamic University, Indonesia, martinkustati@uinib.ac.id

\section{Yunisrina Qismullah Yusuf}

Dr., corresponding author, Universitas Syiah Kuala, Indonesia, yunisrina.q.yusuf@unsyiah.ac.id

\section{Hallen}

Imam Bonjol State Islamic University, Indonesia, hallenabubakar@gmail.com

\section{Hidayat Al-Azmi}

Imam Bonjol State Islamic University, Indonesia, marvelouse_80@yahoo.co.id

\section{Sermal}

Imam Bonjol State Islamic University, Indonesia, sermalpohan@gmail.com

The purpose of this quantitative and qualitative mixed research is to describe the impact of English teachers' attitude on the learning outcomes of multicultural students in six Islamic secondary schools. The obstacles faced in teaching these students were also investigated. About 30 respondents that comprised 20 female teachers and 10 male teachers filled out questionnaires. From these teachers, 12 English teachers were further selected for interviews and classroom observations. The findings of the study revealed that $90 \%$ of the teachers had positive attitudes towards multicultural students and gave positive impacts to the students' good learning outcomes. Meanwhile, $10 \%$ of the teachers had a negative attitude towards multicultural students, and this gave negative impacts on the students' low learning outcomes. Moreover, the obstacles faced by English teachers in the learning process with these students come from the content of English teaching materials, from within the students themselves, and from the environmental responses to the different linguistic, social, and cultural conditions of these students. To overcome these obstacles, some teachers used various learning strategies that could accept and appreciate the multicultural conditions of students. Some of the strategies that these teachers use are further discussed in the paper.

Keywords: multicultural classroom, Islamic secondary schools, attitudes, obstacles, EFL

Citation: Kustati, M., Yusuf, Y. Q., Hallen, Al-Azmi, H., \& Sermal. (2020). EFL Teachers’ Attitudes towards Language Learners: A Case of Multicultural Classrooms. International Journal of Instruction, 13(1), 353-370. https://doi.org/10.29333/iji.2020.13124a 


\section{INTRODUCTION}

Indonesia is known as a multilingual and multicultural country. Today there are 650 languages and dialects spoken in Indonesia out of 6000 indigenous languages in the world (Masinambow \& Haenen, 2002). However, the Indonesian language is chosen as the national language that aims to unite the nation, without giving superiority to a certain group. Despite Indonesian is used extensively in various regions of Indonesia (Paauw, 2009), people still use the local languages (Javanese, Sundanese, Madurese, Acehnese, Riau, etc.) in their daily communication (Paauw, 2009, Kustati, 2014) as a form of their existence, ethnic and cultural identity (Yusuf, Aziz \& Kamarullah, 2017), whether they live in rural or urban areas. The local languages they use may occur in their neighborhood, place of work, school, or elsewhere (Aziz, et al., 2017; Chaer, 2007; Ulfa, Isda \& Purwati, 2018). Besides, there is a tendency to maintain the language of each region without leaving the use of Indonesian as the national language (Aziz, et al., 2017).

Multicultural presence in existing schools often raises problems and can become obstacles in carrying out the learning process in various subjects. While teachers in other regions can carry out EFL education based on the local culture, teachers teaching in a multilingual region are confronted with linguistic and cultural issues that may affect the learning process. This is because most English language teaching in West Sumatera is carried out in Indonesian and other local languages to assist in the smooth communication of language learning in the classroom (Besral, 2016). However, based on research conducted by Irwansyah (2015), the impact of bilingual contact and culture cause an ambivalent phenomenon. That is, between taking a policy of maintaining the same language (monolingual) and a common culture (monocultural) or making a decision to be open to other languages and cultures (in this case English). These sometimes lead learners to face difficulty in mastering the four language skills, namely listening, speaking, reading, and writing in English.

In the case of language and cultural barriers, the teacher should find the right strategy to solve the communication problem. English teachers are required to have the knowledge, willingness, and skill to introduce and engage students in a global context (Seeberg \& Minick, 2012). The role of cultural and linguistic understanding is also other competencies that teacher's must-have. Cross-cultural disposition should be done in a transformative or through practical experience (cross-cultural encounter), not just theoretical. The quality of a school can has a positive and negative impact on the implementation of the learning process in teaching English to learners of a multicultural background.

Various studies have been carried out on the attitude of English teachers to multicultural education. Quantitative research by James (2004) in the southeastern U.S.A. studied 50 elementary teachers from five schools who taught second and fifth grades on their perception on teaching multicultural students and their training toward teaching multicultural children. A questionnaire was given to the respondents to measure their attitudes and perceptions of cultural and diversity awareness. The results showed that in general, the teachers' attitudes toward cultural diversity were positive, however, they 
also informed that they felt insufficient with pre-service experiences and training to work with multicultural children. Another study by Perkins (2012) investigated the multicultural awareness, knowledge, skills, and attitudes of prospective teachers in the Midwest region of U.S.A. This mixed-methods study used a survey and interviews for data collection. The findings disclosed that these teachers felt that they were being prepared to teach multicultural students; however, the interview results showed that they did not feel as confident in their preparation to teach multicultural students.

Furthermore, Gürsoy (2016) studied 272 teachers from 29 countries who have students and work at international schools. The teachers' attitudes toward multicultural education were gathered through the 'Teacher Multicultural Attitude Survey (TMAS)'. The data were analyzed statistically using standard deviation, percentages, and t-tests. The results revealed that the teachers' attitude towards multicultural education differs from each other according to gender, native or foreign teacher, and experiences of living abroad. Meanwhile, in Malaysia, Yusuf, Marimuthu and Yusuf (2018) examined the multicultural awareness among primary school teachers. A questionnaire was distributed randomly to 50 primary school teachers from three ethic types of primary schools: Tamil, Chinese and Malay primary schools. Five teachers were further chosen to be interviewed for gaining detailed information. The findings revealed that multicultural teachers' education was still at the medium level. The study further suggests that more multicultural awareness campaign at all schools in Malaysia should be conducted to achieve a form of one Malaysian society.

Concerning this situation, West Pasaman, a regency of West Sumatra, Indonesia, is chosen as the place of research because it is one of the transmigration areas in Indonesia. This is where the Indonesian government moves people from densely populated areas of Indonesia to work in less populous areas of the country. Thus, the distribution of the public schools in West Pasaman is parallel with the distribution of the people coming from various cultures, who play the roles of both the teachers and the students at the schools. In West Pasaman there are six public Islamic secondary schools (or known as Madrasah Tsanawiyah Negeri) scattered in different areas and districts. Besides, in the subject of English on the national exam in 2016, these schools ranked 18 out of 19 in the regency. As being in a position of second to last, this is alarming, and further examination into this problem needed to be investigated.

Based on the preliminary study in one of the six public Islamic secondary schools, almost every classroom in the school consists of students coming from different ethnic groups, namely Minang, Batak, Java, Malay, and others, each with their mother tongue. These mother tongues are the tools of communication used by students with the same ethnic backgrounds. It is deemed that the situation of these multicultural students certainly influences the learning of English as one of the foreign languages taught in these schools. Therefore, it is interesting to examine the attitude of English teachers in this school, MTsN (Madrasah Tsanawiyah Negeri) Pasaman Barat, whether they affect students learning, and what have the teachers done to overcome the multicultural problems of learners in the classroom. The lessons learned from the findings of this 
research can provide insights and guidance not just to teachers in Indonesia, but to other countries that comprise multicultural students as well.

Three research questions are formulated for this research:

(1) What are the attitudes of English teachers toward multicultural students at the Islamic secondary school of West Pasaman, Indonesia?

(2) What is the impact of English teachers' attitude to the learning outcomes of the multicultural students?

(3) What are the obstacles faced by the English teachers in teaching English to the multicultural students?

Taking into consideration the previous studies and the situation during the preliminary observations at the six public Islamic secondary schools above, this study intends to describe the attitude of English teachers' teaching multicultural students in Indonesia, especially those teaching in the West Pasaman area. This research is deemed essential because so far, no published work has been done in this topic on this area in Indonesia. The results of this research can assist other researchers in the same field to better recognize the attitudes of non-native English teachers in teaching students with diverse first languages and cultural backgrounds.

\section{LITERATURE REVIEW}

\section{Education in Multicultural Regions}

In countries of multiculturalism, multicultural learning is a policy in educational practice in acknowledging, accepting, and affirming human differences and equations associated with gender and race. Multicultural learning is a nation's education program so that multicultural communities can participate in realizing an ideal democratic life for their nation (Banks et al., 2005). In a broader context, multicultural education seeks to help unite the nation democratically, emphasizing the perspective of a plurality of peoples of different nations, ethnicities, and cultural groups. Thus, school learning is conditioned to reflect the practice of democratic values. The curriculum represents different cultural groups in society, language, and dialect, where students speak of respect with each other and uphold the values of cooperation, rather than talk about competition and prejudice among several different students in terms of race, ethnicity, culture, and social status groups. Multicultural education also aims to provide justice and equality for all learners (Sleeter, 2001), and this is needed in the understanding and implementation process of a teacher (Seeberg \& Minick, 2012). When applied properly, it will benefit the community itself (Parrish \& Linder-Van Berschot, 2010). With sufficient understanding and experiences in the multi-cultural field, teachers are expected to have positive perceptions and attitudes toward the diversity of their students. In some studies, it has been found that teachers who are trained with materials that fit the students' diverse cultural needs will have a better acceptance of multicultural education (Delk, 2017). 


\section{Teachers Teaching Multicultural Students}

To teach a language classroom full of multilingual and multilingual students is not as easy as flipping a coin for teachers. Various elements make up the interaction involved in the teaching-learning process; these include "the teacher's intervention, peer interactions, learning methodology, materials, management of classroom space, etc." (Garrote, 2014, p. 429). To the students themselves, Banks and Banks (2010) mentioned potential inhibiting factors faced by multicultural students in a language classroom:

- Limitations of teachers from the schools to support developments related to language instructors.

- Assessment tools and assessors who have negative perceptions and attitudes toward learners' abilities in migration areas and tend to assume they have substandard abilities.

- Limited opportunities in developing their mother tongue at higher levels of education.

- There is a misunderstanding be it caused by the differences in language or culture that the teachers or the students have.

Garrote (2014, p. 429) further observed that "the foreign language classroom has certain characteristics that make the interaction a permanent teaching tool, however, in multilingual learning contexts it is necessary to provide an inclusive learning environment that promotes the integration of participants from different cultures in the teaching-learning process". Consequently, the teachers' attitudes in facing these settings will shape or break the promotion of integration. Again, teacher' attitudes are determined by the education and background they have. Attitudes can be described as an aspect and feeling in general, whether positive or negative, using psychologically responsive objects, and is a factor that strongly determines one's behavior (Banks \& Banks, 2010; Gürsoy, 2016). Teachers who have a positive attitude to differences and diversity can lead students to become individuals who have a positive attitude toward the differences of others. The positive attitudes of teachers are reflected in their habits and the atmosphere they create in the teaching process each day. Conversely, negative attitudes from a teacher harm the character and success of learners.

\section{Learning Outcomes}

The learning outcome is a specific level of success from learning tasks, or a certain level of skill in school or academic tasks (Zimmerman, 2002). Academically, learning outcomes constitute a particular level of acquisition or skill that result in academic work assessed by teachers, through standardized tests, or a combination of both. Also, Ramsden (2003) defined the learning outcomes of learning as a result obtained, which results in the form of impressions that result in changes in the individual as the result of learning activities. It is an assessment of educational outcomes, to find out the extent to which students learn after learning and training deliberately (Gibbs, 2010). The embodiment of the resulting form can be either oral or written, and the skills and problem solving can be directly measured or assessed using standardized tests (Brown, 2005). So, it can be concluded that the learning outcomes of learning are a change in 
terms of behavioral skills or ability that can increase over time and not due to the growth process, but the existence of learning situations.

Experts have suggested two factors that affect the learning outcomes, namely (Cohen \& Levinthal, 1990; Tschannen-Moran \& Hoy, 2001):

(1) External factors are factors that come from the outside, including (a) non-social factors, which include air condition, air temperature, weather, time, place, and tools used for learning. These factors can directly affect a person's psychological impact on the results of learning outcomes that will be obtained by students, and (b) social factor is the human factor, whether the human is present, absent, or not directly present.

(2) Internal factors are factors that come from within the self, including (a) physiological factor that is the physical state. Physical state stands behind the learning activities; where a healthy physical condition will give a positive influence in the process of learning, so the person's learning process will provide optimal results. Then (b) psychological factors, which include interest, talent, intelligence, personality, and motivation of learners. Many factors are included in the psychological aspects that can affect the quantity and quality of a person's academic achievement, including the level of intelligence, attitudes of students to a lesson, talents, and interests of students, as well as student motivation. The motivation of students can be intrinsic motivation (which comes from within the student's self, where students do the learning process because she likes it) or extrinsic motivation (which comes from outside the student's self, where students want to get good grades/optimal learning outcomes).

(3) Learning approach factor is a type of effort in learning a person has that includes strategies and methods used by him or her to conduct activities to learn.

Therefore, the learning outcomes are influenced by internal factors, external factors, and learning approach factors, where the internal factors consist of physiological aspects and psychological aspects, while external factors consist of social aspects and non-social aspects. From the learning approach factors, student learning outcomes can be seen from their task, assignment, test, and exam score documents that measure them academically at the end of study completion (Bachman \& Palmer, 2010). The grades are influenced by many things, among them is, of course, the quality of teachers. These teachers are also measured through the level of formal education that they have completed, and their mastery of teaching methods and materials to be taught to the students. Besides, the main indicators of student learning outcomes in Indonesia are the students' achievements and behaviors. In the achievement of the absorbability of materials taught, either individually or in groups, the measurement of absorptive capacity is usually done by determining the Minimum Passing Criteria or Kriteria Ketuntasan Minimal (KKM). Meanwhile, the behaviors outlined in the learning objectives are to be achieved by students individually or in groups. 


\section{METHOD}

This study used a mixed-method; it is a type of research that combines both qualitative and quantitative methods in one study (Johnson \& Onwuegbuzie, 2004). The methods used are further elaborated in the next sub-headings.

\section{Participants}

A number of 30 respondents (20 female teachers and 10 male teachers) randomly participated in filling out the questionnaire. These teachers taught the 7th, 8th and 9th grade of six public Islamic secondary schools in West Pasaman, Indonesia. These teachers are coded T1-T10 in the paper. From these respondents, 12 were further selected based on their consent and availability to be interviewed and observed while they were teaching to complement the data from the questionnaire.

\section{Instruments and Data Collection}

The instruments used to collect data were the questionnaire, interview, and observation. The questionnaire was constructed based on theoretical studies. This instrument was to answer the first research question on the impact of English teachers' attitude to the learning outcomes of multicultural learners. The teacher participants were gathered in one room after the monthly meeting of MGMP (Musyawarah Guru Mata Pelajaran or the Deliberation of Subject Teachers, a monthly training for teaching methodology held by the Department of Education in the province). It took them about 15 to 30 minutes to fill in the questionnaire. Personal data was on the first page, and responses to attitudes towards language learners in multicultural classrooms items are on pages 2-3. There were 30 items and each item is classified into 5 points of the Likert scale, ranging from strongly agree to strongly disagree (McLeod, 2008).

Next, to study the students' English scores was to answer the second research question. The data is from documents, i.e. the students' report cards. Each teacher gave their students' outcome in the form of scores from test results of the first and second semester of this school year. The scores were categorized based on classes; since there were ten English classes from grade 7 (4 classes), 8 (three classes) and 9 (three classes), they were coded into $\mathrm{C} 1-\mathrm{C} 10$. For each class, the students' scores were summed and calculated for the average score, and further noted the maximum and minimum score of the students in the class. These scores were linked to the teachers' questionnaire results, whether their positive or negative attitude toward multicultural students affected the students' learning outcome.

To answer the third research question, data were collected through interviews and observations. The interview questions inquired about the obstacles in teaching, and what they did to resolve them. Seven questions were asked in a semi-structured manner to the interviewees. After the questionnaires were filled in and the students' scores were calculated, the researchers then selected 12 out of the 30 teachers purposively to be interviewed and observed. The researchers made appointments with the interviewees for these sessions. The interviews were mainly conducted in a quiet place such as the 
interviewee's home or place of work (i.e. school), and each interview lasted about 20 to 30 minutes. The interviews were recorded on a mobile phone.

For observation, an observation sheet was used to study the situation of the teaching and learning process of these classes. The ten conditions being observed while the teachers were teaching were: the atmosphere of the classroom, teachers' treatment, appreciation, interaction, tolerance, empathy towards the students, rewards, punishments, moral values given to the students, and tasks assigned to the students. One interviewed teacher was observed for one class meeting, thus making a total of 12 observations. Each class meeting was $2 \times 45$ minutes, making a total of 18 hours of observations.

\section{Data Analysis}

After the data were collected, data analysis was done. It is a process of simplification of data for more comprehensive research (Fraenkel \& Wallen 2006), and a process of interpreting data provided by the respondents (Creswell, 2008). The data from the questionnaire and documents (i.e. students' scores in their report cards) were analyzed using descriptive statistics. The results showed the percentage obtained for each item in the questionnaire to answer the first research question.

In the meantime, the results from the interviews were transcribed. Both the results from the interviews and observations were analyzed based on the thematic analysis (Creswell, 2008). The stages included data check (re-examined the data that had been obtained for relevance and sufficiency), classification (reduced the existing data by compiling and classifying the data into a particular pattern in accordance with the needs of research), verify (ensured the validity of the data as in accordance with the informed or not), analysis (simplified words into a form that was easier to read and interpret) and finally, conclusion (concluded data after analysis to obtain answers). Finally, the results from the interviews and observations are reported narratively in this paper.

\section{FINDINGS}

\section{English Teachers' Attitudes towards Multicultural Students}

From the questionnaire, the overall result on the teachers' attitudes towards multicultural students is shown in Table 1.

Table 1

Frequency Distribution of Scores on Teachers' Attitudes towards Multicultural Students

\begin{tabular}{llll}
\hline Interval Class & Category & Frequency & Percentage \\
\hline $90-120$ & Very good & 14 & 46,67 \\
$60-89$ & Good & 13 & 43,33 \\
$30-59$ & Poor & 3 & 10 \\
$0-29$ & Very poor & 0 & 0 \\
Total & & 30 & 100 \\
\hline
\end{tabular}

Table 1 shows that $90.00 \%$ of teachers had a positive attitude towards multicultural classrooms and only $10 \%$ had a negative attitude about it. From these numbers, $46.67 \%$ of teachers were categorized into "very good" and another $43.33 \%$ of teachers were 
categorized into "good" towards multicultural students, and $10 \%$ was "poor". These numbers indicate that most of the teachers perceived themselves as having positive attitudes towards accepting and dealing with multicultural students.

Meanwhile, from the interviews, the teachers informed that the classes they taught consisted of students from various ethnic backgrounds, i.e. Minang, Mandailing, Batak, Malay, and Javanese. This condition was somewhat prominent in this region because it was a new region for transmigration of people from Java, so many families who lived here came from Java. Meanwhile, the indigenous people there were of the Minang ethnic group of West Sumatra province. Besides, there were also students coming from Mandailing and Batak ethnic groups because this region stands near the border next to North Sumatra Province. T4 explained in E1 that:

E1 "Indonesia is a multicultural country. As teachers, we have to be prepared to teach students with different cultural background, first languages and beliefs. We have to be tolerant and respect diversity". [T4]

The finding from the questionnaire showed that most teachers (i.e. 90\%) felt comfortable teaching multicultural students and interacting with their parents. They did not find any difficulty in teaching the lessons and believed that the multicultural environment would help the careers of their students in the future since it reinforced tolerance among learners. The teachers also believed that the learners would benefit from being bilinguals or multilinguals.

Meanwhile, the three teachers (i.e. 10\%) had negative attitudes towards the multicultural classroom. It was supported by the observations that these teachers had difficulty in accepting the students' different English accents due to the influences from the first languages or mother tongues. This attitude caused them to be more authoritarian and rigid in the classroom and led to a wearying teaching and learning environment.

\section{Impact of English Teachers' Attitude on the Learning Outcomes}

The researchers explored the impact of teachers' attitudes toward the learning outcomes of the multicultural students by looking at their scores in their report cards. Table 2 further shows the average scores in English subject achieved by the students.

Table 2

Average Scores in English Subject for Each Class

\begin{tabular}{llllll}
\hline No & Grade & Class & Average & Highest score & Lowest score \\
\hline 1 & 7 & C1 & 78.8 & 100 & 12 \\
2 & 7 & C2 & 80.2 & 95 & 61 \\
3 & 7 & C3 & 94.4 & 100 & 80 \\
4 & 7 & C4 & 72.8 & 78 & 65 \\
5 & 8 & C5 & 88 & 94 & 73 \\
6 & 8 & C6 & 72.7 & 94 & 40 \\
7 & 8 & C7 & 55.7 & 94 & 13 \\
8 & 9 & C8 & 47 & 78 & 18 \\
9 & 9 & C9 & 65 & 86 & 40 \\
10 & 9 & C10 & 58.9 & 100 & 38 \\
\hline
\end{tabular}


Based on Table 2, the learning achievement of the English students at the school varied among the classes. In C3, the students reached an average score of 94.4 with the highest score at 100 and the lowest at 80 . This condition indicates that the homogeneous students had good English achievements because every student passed the minimum passing grade required by the school. While in another class, $\mathrm{C} 1$, the average score is 78.5 with the highest score of 100 and the lowest score of 12. This condition shows that student achievement in the class varied, in which there were students who were able to achieve above the minimum passing grade, and those who cannot even pass the minimum passing grade. The same condition was also found in classes C8 and C9.

It is interesting to note that the higher the grade levels got, the lower the average score of the class. In grade 7 (classes C1-C4), the average of English learning achievement varied from 72.8 up to 94.4. However, in grade 8 (classes C5-C7), the average of English learning achievement only reached 55.7 to 88. Meanwhile, in grade 9 (classes C8-C10), the average of English learning achievement only reached 47 to 65 . A more in-depth analysis of data found that the average of English learning achievement with very low average scores in grade 8 and 9 (i.e. C7, C8, and C10) was taught by teachers who have a negative attitude toward multicultural students, and these teachers were those who had longer work experiences. The average score of class C7 is of 55.7, and this class was taught by the teacher who is categorized into the "poor" category (i.e. a score of 55) in terms of attitude towards multicultural students. As for C10 who had students with an average score of 47 , it was also taught by another teacher in the "poor" category" (i.e. a score of 53).

The observations also supported the above finding that teachers who can appreciate the students' multicultural background provided better motivation and confidence to the students. They were able to stop classroom mocking, for example, due to the influence of the first language into English pronunciation, before the students got out of hand. The teachers could better accept the different English accents without pressuring the students too much to provide the 'perfect' pronunciation. The learning atmosphere was seen to be more friendly and relaxed. However, in the classroom that was taught by the teachers who had a less positive attitude towards multicultural students, the ambiance was more tensed. T9 informed in E2:

E2 “There are students who pronounce /za/ as /sa/ or /za/ as /dza/. They face difficulty in pronunciation because of their first language influences. It is like, their tongues become stiff when they try to speak. Their intonation is also still affected by mother tongue. So, I ask them to always repeat over and over again until they get it right." [T9]

The influence of the students' mother tongues into English learning was much felt by the teachers. The largest effect was seen in the aspect of pronunciation. Another example was the pronunciation of have [hæv] that was pronounced as [hev] by most students, perhaps because their mother tongues, and Indonesian as well, do not have the vowel [æ]. 
From the researchers' observation, the three teachers who were in the "poor" category of attitude towards multicultural students were seen to pressure their students to produce the 'perfect' pronunciation and intonation until some students were seen uncomfortable, stressed and of course, this made an impact on their learning outcomes. Students' demotivation, insecurity and anxiety expressions were noticed during the teaching and learning process. It is possible that this situation influenced their learning and trailed them to achieve low English scores.

\section{Obstacles Faced by the English Teachers}

Another aim of this research is to investigate the obstacles faced by English teachers in teaching multicultural students. From the interviews and observations, there were eight obstacles presented by the teachers and they are shown in Table 3.

Table 3

Obstacles in Teaching English to Multicultural Students

\begin{tabular}{llll}
\hline No & Obstacles & Number & Note \\
\hline 1 & Difficulties from the influence of & $12(40 \%)$ & $\begin{array}{l}\text { Affected pronunciation, intonation, the } \\
\text { accent in speaking English }\end{array}$ \\
& L1 & $4(13.3 \%)$ & Based on cultural backgrounds/ethnic \\
2 & Students gathering in groups & $4(13.3 \%)$ & Students speaking different languages \\
3 & Comprehension & $4(13.3 \%)$ & Name-calling, racism \\
4 & Disrespectful students & $4(13.3 \%)$ & Not interested in learning \\
5 & Motivational problem & $1(3.3 \%)$ & Related to culture and communication \\
6 & Teaching difficulty & $1(3.3 \%)$ & Noisy \\
7 & Classroom management & & \\
\hline
\end{tabular}

Table 3 reveals that the biggest obstacle (40\%) in teaching the multicultural classroom is the learning difficulties due to the influence of the first language (i.e. mother tongue) into the foreign language (i.e. English). These influences were noticeable in pronunciation and intonation that further affected the students' various English accents outcome. Thus, as mentioned earlier in the previous sub-section, when teachers did not treat this a major problem in learning English, then the learning atmosphere became more comfortable.

However, for those who treat this as a major problem, then the learning atmosphere became uncomfortable. Based on that interview data, one of the teachers explained that it was the responsibility of every teacher to provide them with knowledge of how to pronounce English letters and words 'properly'. Thus, as students carry with them their first (mother tongue/s) and second (Indonesian) languages with them while learning English, dialect influences were unavoidable and so, the teachers must tolerate it. T17 said in E3:

E3 "Of course there are students who face problems in English pronunciation. I think this is common since they didn't grow up with English as their first language. They learn it later in their lives. So, we try our best to teach them the correct pronunciation and intonation. But of course, it is not their fault. A lot of patience is needed in the process". [T17]

Other problems that teachers faced were students gathering in groups, comprehension problem, disrespectful students and motivational problem (each with 13.3\%). It was 
grueling for the teachers to see when students gather in certain groups based on their ethnicity during recess or break times, for example, students of the Mandailing origin only gathered with other Mandailing students, Javanese students only be-friended other Javanese students, etc. It is understandable that perhaps students did so because they felt more contented to be with those who have mutual understanding and similar background in terms of language and culture. Thus, these groupings sometimes led to a distancing of students from one another. When less communication occurs among these multicultural students, prejudice and racism occur. And so, sometimes it is evidenced in the classroom observation that there were disrespectful students who would mock other students if their English pronunciation sounded 'funny' due to its accent that was influenced by the first or second language.

Therefore, to overcome the problem, teachers had to quickly mediate the situation by calming the students down and constantly reminding them about respect and diversity. Furthermore, in group work either in class or out of class, it was common that teachers would put them up in diverse groups for activities in the classroom. This act was done so that diverse students would get to know each other, understand and accept their differences, and build respect towards one another, as explained by T12 in E4. Besides that, Indonesian was encouraged to be used in school grounds, without disrespecting the mother tongues, so that miscommunication can be avoided, as informed by T14 in E5.

E4 "Sometimes there are students who read English texts with intonation and dialect of their mother tongues, then there are students who would mock, ridicule or laugh at them. So, teachers must be ready and be prepared to face this situation wisely so that the students being picked on would not lose face, or feel demotivated to study English. For those students who have less respect towards diversity, we remind them, all of our students, all the time that our diversity is a blessing and we must respect and tolerate each other. In school or class activities, we put them in a diverse group of students so that they can get to know each other better and learn from each other". [T12]

E5 "We understand that these students have different languages that they speak at home with their families; they have their own cultures and believes. So, we encourage students to always speak Indonesian in school to avoid miscommunication and build up respect among the students". [T14]

Other obstacles are teaching difficulty and classroom management. In teaching difficulty, this was related to culture and communication. For example, T13 explained that once she almost misinterpreted the tone of a Bataknese student when speaking to her with a higher and louder intonation, meanwhile at the same time a Javanese student was expressing a similar matter to her with a lower and softer intonation. Thus, this did not mean that the Bataknese student was rude or bad-mannered, but his language was influenced by the intonation of his mother tongue that sounded normal to him. Nevertheless, these obstacles are each at $1 \%$ and were not such significant obstacles in teaching the multicultural students. 


\section{DISCUSSION}

This paper investigated the effect of English teachers' attitude on the learning outcomes of multicultural students in six Islamic secondary schools of West Pasaman, Indonesia. The results revealed that $90.00 \%$ of teachers had a positive attitude towards multicultural classrooms and only $10 \%$ had a negative attitude about it. Teachers who reflect this situation as positive believed that the multicultural environment can later enhance the future profession of their students because it can strengthen their tolerance towards others. This is as proposed by Mahfud (2006) who described the objective of multicultural education as providing equal opportunities for every learner in school in the form of mutual respect. By doing so, learners are expected to be able to accept differences and criticism and form empathy and tolerance towards others regardless of their class, status, and gender (Nikawanti, 2017).

In the meantime, the other $10 \%$ of teachers who had a negative attitude towards their students' multicultural beings emphasized on their students' different English accents due to the influences of their mother tongues. This attitude caused them to be stricter in the classroom and made the learning environment more wearisome for the students. In consequence, a study by Dongshan (2017) showed that teachers favored by students are those who understand their students, care for students, accept students' diversity, have a strong sense of responsibility, and able to adapt themselves to the needs of students. Therefore, when teachers pose a positive attitude and engage with multicultural students equally in the classroom, it can help stimulate students' enthusiasm for learning and improve classroom efficiency (Dongshan, 2017).

Basically, teachers' attitudes in multicultural classrooms and their impact on students' English proficiency are made up of a variety of factors that influence them, among them are personal experience, cultural learning, mass media, institutions or educational institutions, and emotional factors within the individual (Banks \& Banks, 2010; Irwansyah, 2015). All of these factors have respective roles in shaping teachers' attitudes towards multicultural students. Accordingly, the teachers' attitude towards multicultural students also made a great impact on the students' learning outcomes. Positive attitude increased students' driving force to learning and thus increased their scores in assignments and exams. On the other hand, negative attitude decreased their interest in learning and weakened their scores in assignments and exams. This concurs with the findings by Connor et al. (2005) and Curby, Rimm-Kaufman and Ponitz (2009) on correlation studies that suggested teachers who use more positivity in the classrooms would see more academic gains from their students. Relationship quality between teacher and students is one of the predictors of student grades (Murray, 2009). Moreover, evidence from previous studies also proved that teachers' who are competent in promoting students' good attitudes and behaviors lead to students' long-term success (Blazar \& Kraft, 2017).

Regarding the obstacles faced by the teachers in teaching the multicultural classroom, the biggest problem is the students' learning difficulties due to the influence of the first language while learning English. In line with this finding, Suryanto (2014, p. 80) also 
claimed that "(students') first language acquisition that is far different from English constitutes a significant barrier for Indonesian students to make a progress". Moedjito and Harumi (2008) added pronunciation is among the hindrance of Indonesian students in acquiring English because the sound systems in these two languages are very different. Furthermore, to overcome problems of students befriending only others within their ethnic circle was by having them work in groups of diverse students in classroom tasks. Howard (2003) asserted that this is a part of being culturally responsive teachers; this is where teachers are aware of the significant role that race and culture play in the way that students learn. Hill (2012) also noted that as educators today, it is critical for teachers to acknowledge and understand the diversity of students and know how to use their cultural experiences to enhance the classroom environment.

In Indonesia, diversity is unavoidable and a consequence that must be lived by schools located among people of different ethnicity, mother tongues, and cultural background. The motto of diversity in this country is Bhinneka Tunggal Ika, which means "unity in diversity"; it is "a spirit which must be assimilated in mutual love, accept differences, and respect" (Nikawanti, 2017, p. 228). The process of learning English is by the use of the mother tongues among the multicultural students (Butzkamm, 2003; Tang, 2002). In this study, the mother tongues or regional languages used were Mandailing, Bataknese, Minang, Malay, and Javanese. In interaction among diverse students, Indonesian plays an important role as mediation to bridge communication. These teachers also use Indonesian to mediate communication in the implementation of learning English with these students.

\section{CONCLUSION}

Teachers' attitudes towards multicultural students varied from 'very good', 'good', to 'poor'. In this study, 90\% of teachers were in the 'very good' and 'good' category, meanwhile, only $10 \%$ were in the 'poor' category. These numbers indicate that most of the teachers who taught English in the six Islamic secondary schools of West Pasaman, Indonesia, had positive attitudes towards multicultural students. Moreover, the teachers' attitudes towards these multicultural students had an impact on their learning outcomes. The teachers who had a less accepting attitude towards multicultural students tend to produce students with lower English scores. Meanwhile, teachers who can accept and appreciate multicultural students tend to produce better learning outcomes from these students.

The obstacles faced by English teachers in the learning process with multicultural students included difficulties in learning due to the influence of L1, students gathering in their ethnic circle, comprehension problems, disrespectful students, motivational problem, teaching difficulty and classroom management. These obstacles were overcome by using various learning strategies that could accept and appreciate the multicultural conditions of students. Some of the strategy's teachers use to improve students' English were to practice English pronunciation. Meanwhile, to avoid students to always gather in their ethnic circle and spread out more to other diverse students in the school, the teachers made them work in diverse groups in classroom tasks. Meanwhile, to increase their tolerance towards multi-cultures in the classroom, the 
teachers gave them understanding and guidance to increase their tolerance on ethnic diversity. They also played fair and did not differentiate between students. Furthermore, Indonesian was encouraged to be used by students and fewer mother tongues when they are in diverse groups to avoid miscommunication.

The results of this study have provided an overview of the impact of English teachers' attitude on the learning outcomes of multicultural students in six Islamic secondary schools of West Pasaman, Indonesia. The obstacles faced in teaching these students were also discussed. Thus, future research is suggested to focus on collecting more data from other schools with multicultural students in the country. It is also recommended to collect data from the students as well on the state of multiculturalism in schools. The data from this study was collected from one regency of the island, thus greater access to data from other regencies in the country would better endorse the conclusions drawn from this study.

\section{REFERENCES}

Aziz, Z. A., Yusuf, Y. Q., Raisha, S., \& Kamaliah, N. (2017). Language maintenance of the Tionghua speakers towards their heritage language in Aceh. Proceedings of the International Seminar on Sociolinguistics and Dialectology (pp. 278-283). University of Indonesia, Jakarta.

Bachman, L. F., \& Palmer, A. (2010). Language assessment in practice. Oxford: Oxford University Press.

Banks, J. A. (2001). Approaches to multicultural curriculum reform. Multicultural Education: Issues and Perspectives, 4, 225-246.

Banks, J. A., \& Banks, C. A. M. (2010). Multicultural education: Issues and perspectives. Hoboken, NJ: John Wiley \& Sons.

Banks, J., Cochran-Smith, M, Moll, L., Richert, A., Zeichner, K., LePage, P., DarlingHammond, L., Duffy, H., \& McDonald, M. (2005). Teaching diverse learners. In L. Darling-Hammond, \& J. Bransford (Eds.), Preparing teachers for a changing world: What teachers should learn and be able to do (pp. 232-274). San Francisco, CA: Jossey-Bass.

Besral, B. (2016). Pembelajaran Bahasa Inggris untuk anak-anak [Teaching English to children]. Ta'dib, 13(1), 10-17.

Blazar, D., \& Kraft, M. A. (2017). Teacher and teaching effects on students' attitudes and behaviors. Educational Evaluation and Policy Analysis, 39(1), 146-170.

Brown, S. (2005). Assessment for learning. Learn. and Teach. in High. Edu., 1, 81-89.

Butzkamm, W. (2003). We only learn language once. The role of the mother tongue in FL classrooms: Death of a dogma. Language Learning Journal, 28(1), 29-39.

Chaer, A. (2007). Linguistik umum [General linguistics]. Penerbit Rineka Cipta. 
Cohen, W. M., \& Levinthal, D. A. (1990). Absorptive capacity: A new perspective on learning and innovation. Administrative Science Quarterly, 35(1), 128-152.

Connor, M. C., Son, S., Hindman, A. H., \& Morrison, F. J. (2005). Teacher qualifications, classroom practices, family characteristics, and preschool experience: Complex effects on first graders' vocabulary and early reading outcomes. Journal of School Psychology, 43, 343-375.

Creswell, J. W. (2008). Educational research: Planning, conducting, and evaluating quantitative and qualitative research. Upper Saddle River, NJ: Pearson/Merrill.

Curby, T. W., Rimm-Kaufman, S. E., \& Ponitz, C. C. (2009). Teacher-child interactions and children's achievement trajectories across kindergarten and first grade. Journal of Educational Psychology, 101, 912-925.

Delk, T. (2017). The efficacy of multicultural education training in teacher credentialing programs: A descriptive case study (Unpublished doctoral dissertation). University of Phoenix, Tempe.

Dongshan, L. (2017). What characteristics of a teacher impress students most? Advances in Social Science, Education and Humanities Research, 99, 148-151.

Fraenkel, J. R., \& Wallen, N. E. (2006). How to design and evaluate research in education. New York: McGraw-Hill Publishing.

Garrote, P. R. (2014). Second language learning in a multilingual classroom: Didactic interaction development. Journal of Educational and Social Research, 4(3), 429-436.

Gibbs, G. (2010). Using assessment to support student learning. Leeds: Leeds Met.

Gürsoy, A. (2016). Teacher's attitudes toward multicultural education according to some variables: native or foreign. Romanian J. of Exp. Applied Psychology, 7(2), 60-72.

Hill, A. L. (2012). Culturally responsive teaching: An investigation of effective practices for African American learners (Unpublished doctoral dissertation). Loyola University Chicago, Chicago.

Howard, T. C. (2003). Culturally relevant pedagogy: Ingredients for critical teacher reflection. Theory into Practice, 42, 195-202.

Irwansyah, D. (2015). Pendidikan multikultural dan pengajaran bahasa asing [Multicultural education and foreign language teaching]. ADDIN, 7(1), 1-18.

James, J. L. (2004). Teachers' attitudes and perceptions of multicultural and diversity awareness in elementary schools (Unpublished doctoral dissertation). University of Tennessee, Knoxville.

Johnson, R. B., \& Onwuegbuzie, A. J. (2004). Mixed methods research: A research paradigm whose time has come. Educational Researcher, 33(7), 14-26.

Kustati, M. (2014). An analysis of code-mixing and code-switching in EFL teaching of cross-cultural communication context. Al-Ta'lim Journal, 21(3), 174-182. 
Mahfud, C. (2006). Pendidikan multikultural [Multicultural education]. Yogyakarta: Pustaka Pelajar.

Masinambow, E. K., \& Haenen, P. (2002). Bahasa Indonesia dan bahasa daerah [Indonesian and regional languages]. Jakarta: Yayasan Obor Indonesia.

McLeod, S. A. (2008). Likert scale. Retrieved from https://www.simplypsychology.org/likert-scale.html.

Moedjito, \& Harumi, I. (2008). Perceptions of the seriousness of mispronunciation of English speech sounds. TEFLIN Journal, 19(1), 70-90.

Murray, C. (2009). Parent and teacher relationships as predictors of school engagement and functioning among low-income urban youth. J. of Early Adolescence, 29, 376-404.

Nikawanti, G. (2017). Multicultural education for early childhood. Advances in Social Science, Education and Humanities Research (ASSEHR), 58, 8228-232.

Paauw, S. (2009). One land, one nation, one language: An analysis of Indonesia's national language policy. Uni. of Rochester Working Pap. in the Lang. Sci., 5(1), 2-16.

Parrish, P., \& Linder-VanBerschot, J. (2010). Cultural dimensions of learning: Addressing the challenges of multicultural instruction. The International Review of Research in Open and Distributed Learning, 11(2), 1-19.

Perkins, R. M. (2012). The multicultural awareness, knowledge, skills and attitudes of prospective teachers: A quantitative and heuristic phenomenological study (Unpublished doctoral dissertation). University of Missouri, Columbia.

Ramsden, P. (2003). Learning to teach in higher education. New York: Routledge.

Seeberg, V., \& Minick, T. (2012). Enhancing cross-cultural competence in multicultural teacher education: Transformation in global learning. Int. J. of Multic. Edu., 14(3), 1-22.

Sleeter, C. E. (2001). Preparing teachers for culturally diverse schools: Research and the overwhelming presence of whiteness. Journal of Teacher Education, 52(2), 94-106.

Suryanto. (2014). Issues in teaching English in a cultural context: A case of Indonesia. The Journal of English Literacy and Education, 1(2), 75-82.

Tang, J. (2002). Using L1 in the English classroom. English Teach. Forum, 40, 36-43.

Tschannen-Moran, M., \& Woolfolk Hoy, A. (2001). Teacher efficacy: Capturing an elusive construct. Teaching and Teacher Education, 17, 783-805.

Ulfa, M., Isda, I. D., \& Purwati. (2018). The shift of Acehnese language: A sociolinguistic study to preserve regional languages. Studies in English Language and Education, 5(2), 161-174.

Yusuf, Q., Marimuthu, S., \& Yusuf, Y. Q. (2018). Multicultural awareness and practices among Malaysian primary school teachers. Al-Ta'lim Journal, 25(2), 97-107. 
Yusuf, Y. Q., Aziz, Z. A., \& Kamarullah. (2017). A lonely inang: A case study of a Bataknese mother's language loss. Proceedings of the Seminar Tahunan Linguistik 2017 (pp. 539-544). Universitas Pendidikan Indonesia, Bandung.

Zimmerman, B. J. (2002). Becoming a self-regulated learner: An overview. Theory into Practice, 41(2), 64-70. 